\title{
Effect of Gravel Size and Weir Height on Flow Properties of Gabions
}

\author{
Shaker A. Jalil Sarhan A. Sarhan Bshkoj S. Hussein Jihan M. Qasim \\ Water Recourses Engineering Department, College of Engineering, University of Duhok, Iraq \\ shaker.abdulatif@uod.ac sarhanabdulsatar@uod.ac $\underline{\text { bshkoj.hussein@uod.ac Jihan.mahmood@uod.ac }}$
}

\begin{tabular}{|l|l|l|}
\hline Submission date:- 14/4/2019 & Acceptance date:- 15/5/2019 & Publication date:-28/5/2019 \\
\hline
\end{tabular}

\begin{abstract}
The variation between flow depth generated in front of gabion barrier and flow rate has been studied in open laboratory flume. Flow profiles have been observed for each of "Transition Flow" and "Overflow" regimes. Effects of gabion height and material coarseness on the upstream flow depth are studied by testing four different gabion heights and four different medium aggregate sizes. The analysis of experimental results showed that the relative decrease in flow depth varies between 38\% and 17\% for "Through Flow" type when material coarseness and discharge increase. In "Transition Flow" regime, increasing material coarseness and discharge causes an average decreases in relative flow depth of $7.6 \%$ and $4.4 \%$ for gabion heights $15 \mathrm{~cm}$ and $30 \mathrm{~cm}$, respectively. Gabion begins to operate as an overflow weir when the average water depth to the gabion height $(\mathrm{H} / \mathrm{P})$ is 1.19 . While the overall average increase in discharge relative to solid weir is $15 \%$. Prediction relationships for flow depth upstream the gabion for each of the three flow regimes is suggested. Also, dimensionless relation to predict discharge coefficient are proposed with good accuracy.
\end{abstract}

Key words: Gabion, Material coarseness, Overflow, Through flow, Transition flow, Free flow.

\section{Introduction}

Rock and gravel have been used as obstacle in streams for lifting water surface level and then reducing flow velocity, these practices motivate creativity and inspiration which had leaded to the creation of the weirs. Gabions are used in river control and storage particularly in attenuating the peak flood of hydrograph by spreading the incoming wave volume out over a long span of time [1]. The aim of constructing weirs across streams and rivers as a sort of hydraulic structure is to modify the upstream flow characteristics. The objectives of weirs could be discharge control, discharge measurement, water surface regulation, flow diversion, and energy dissipation. Generally, weirs are built from concrete, metal or any other rigid materials[2]. Solid constructions across natural stream flow can make ecological changes. The changes happens in the characteristics of flow can affect the environment of river, among that a negative effect on fish spawning and migration[3]. The flow which pass rocks, stones and gravel allows to increase the dissolved Oxygen and affect depositing material[4], which makes this nature friendly structure in favorable to those built from artificial materials. Efforts have been made to analyze this porous structure. Kells [5] solved the spatially varied flow equation listed by Chow [6] to calculate the flow through porous rock fill embankment and over its surface, the study showed that the spatially varied flow equation can evaluate the flow through pores of embankment and the flow over its surface, this conclusion was based on the comparison of calculated values with the physical measurements which had been carried out. The flow surface profile has been studied by Hager and Schwalt [7], the study showed that when the relative flow depth is between $10 \%$ and $40 \%$, the distributions of each pressure, boundary separation and velocity profiles are self-similar and also an undular flow occurs over the extremely long-crested weir. The velocity and pressure fields are studied experimentally on near-full-scale broad-crested weir by Gonzalez and Chanson [8], it was shown that both velocity and pressure fields at the upstream part of the weir rapidly redistribute to generate different type of flow on crest.

Journal of University of Babylon for Engineering Sciences by University of Babylon is licensed under a Creative Commons Attribution 4.0 International License. 
The flow over permeable block ramps has been studied experimentally by Pagliara and Lotti [9], the study forwarded the percentage of flow through ramp base and also found the efficiency of relative energy dissipation as a function to ramp slope, base material and the thickness of base. Abozeid, Mohamed, and Shehata [10] studied the weir with one opening as a pipe then forwarded an empirical formula to estimate the coefficient of discharge. Zachoval et al.[11] studied the discharge coefficient and made a comparison with many earlier studies to find the percentage of error in calculation of flow discharger between those methods. Fadhil and Saa [12] investigated two flow regimes, through flow and transient flow, with relation to the effect of three gravel diameters samples, the study indicated that there is a linear relation between discharge and upstream depth. Gabion check dams designing and building is reported by Grimaldi et al. [13] as a flexible, permeable structure to create a sedimentation bench. The investigation reported that these structures are among the most diffused soil and water conservation practices in site of study. Broad-crested weirs with bottom opening have been investigated to improve the characteristics of flow in both upstream and downstream and then the ecology of streams. Weirs with multiple orifices are also tested for their performance, Ibrahim [14] studied the effect of 9 orifices on the scour and silting downstream and showed that geometry of bed configurations due to scouring process is more better than that without orifices. Free surface flow condition and submerged flow condition on gabion weir has been studied by Mohamed [15], the study included three mean sizes of gravel and has shown that two types of flow occur over the gabion weir and through its body, also showed that the generated water depth upstream gabion weir is less than that caused by solid weir for the same discharge. Salmasi and Sattari [16] have found the value of discharge coefficient by M5 tree model using experimental data, the results showed that the value of this coefficient is less $20 \%$ for the submerged flow compared with free flow, also show that model technique created linear relationship for discharge coefficient and four independent parameters.

It may be noticed from the literature that little effort has been made to study the flow properties of gabions. In the present experimental investigation, the effect of height and aggregate size of gabion in waterways on the accumulated upstream water during seasonal incoming discharge is studied for free flow conditions.

\section{Theoretical Background}

Gabion weirs constructed in streams act as obstacles. The water level in front is a response to the incoming discharge. The flow could happen through porous media only when the generated flow depth is not sufficient to cause overflow on the crest surface, according to that when overflow happens so it is accompanied by base flow. A definition sketch on figure (1) explains the possibility of flow. Three kinds of flow could occur; it's called Through flow, Transition flow and Overflow.

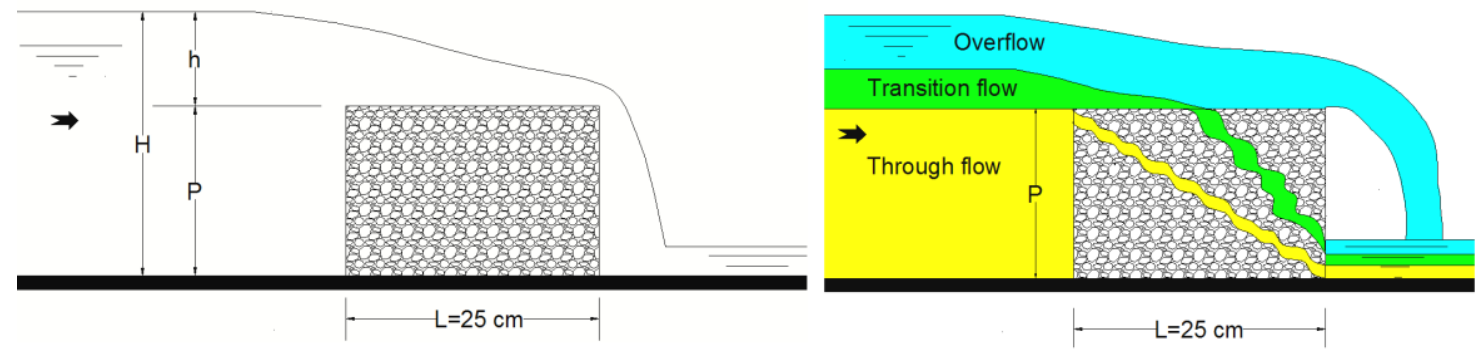

Figure (1) Definition sketch for the investigation

The most important parameters affecting flow discharge over the weir are the head (h), weir height $(\mathrm{P})$, weir length (L) and the width (B). In "through flow", (h) and (P) are not as effective as in "overflow". Accordingly, the functional relationship for the "through flow" regime can be expressed as:

$$
H=f\left(Q, d_{m}, B, L, \rho, g, \mu\right)
$$

For the "transition flow" and "overflow" regimes the functional relationship can be expressed as:

$$
H=f\left(Q, h, P, d_{m}, B, L, \rho, g, \mu\right)
$$


where $\rho$ is fluid density; $\mathrm{g}$ is acceleration of gravity; and $\mu$ is dynamic viscosity of water. As the parameters $\mathrm{L}, \mathrm{B}, \rho, \mathrm{g}$ and $\mu$ are constant quantities, the other parameters are the effective ones on the flow regime.

The most general widely used equation for estimating discharge over the weir is as follows:

$$
\begin{aligned}
& Q=\frac{2}{3} C_{d} B \sqrt{2 g} h^{1.5} \\
& C_{d}=\frac{3 Q}{2 \sqrt{2} B \sqrt{g} h^{1.5}} \\
& C=\frac{2}{3} C_{d} \sqrt{2}
\end{aligned}
$$

And there is additional flow through the body of the weir, so Equation (3) becomes:

$$
\mathrm{C}=\frac{\mathrm{Q}}{\mathrm{B} \sqrt{\mathrm{g}} \mathrm{h}^{1.5}}
$$

Where $\mathrm{C}$ can be called the coefficient of discharge which is a function of the parameters in Equation (2). A non-dimensional relationship for this coefficient can be written as:

$$
\mathrm{C}=\frac{\mathrm{Q}}{\mathrm{B} \sqrt{\mathrm{g}} \mathrm{H}^{1.5}}=\mathrm{f}\left(\frac{\mathrm{h}}{\mathrm{P}}, \frac{\mathrm{d}_{\mathrm{m}}}{\mathrm{P}}\right)
$$

\section{Experimental Work}

The experimental work was carried out at the hydraulic laboratory of engineering college in Duhok University. Physical models have been built in a laboratory rectangular flume $5 \mathrm{~m}$ working length, $0.3 \mathrm{~m}$ wide and $0.45 \mathrm{~m}$ deep. The models were built of gravel of four different medium gradations, $\mathrm{dm}=2.75$, $2.19,1.58$ and $1.13 \mathrm{~cm}$. Four heights of the models were adopted, $\mathrm{P}=15,20,25$, and $30 \mathrm{~cm}$ while the lengths of models were constant of $25 \mathrm{~cm}$, as listed in Table (1). Sixteen tests of different flow rates were run on each physical model and the longitudinal flow profiles were also measured. Figure (2) shows photos for the model. The flow depth has been measured by using point gauges. The point gauge Vernier scale accuracy is $0.01 \mathrm{~mm}$.

\section{Table (1) Details of the models}

\begin{tabular}{ccccc}
\hline Model No. & $\begin{array}{c}\text { Weir height } \\
P(\mathrm{~cm})\end{array}$ & $\begin{array}{c}\text { Weir Length } \\
\mathbf{L}(\mathrm{cm})\end{array}$ & Gravel size dm (mm) & Porosity \\
\hline \hline $1,2,3$ and 4 & 15 & 25 & $1.13,1.58,2.19$ and 2.72 & $33 \%, 34 \%, 36 \%$ and $38 \%$ \\
$5,6,7$ and 8 & 20 & 25 & $1.13,1.58,2.19$ and 2.72 & $33 \%, 34 \%, 36 \%$ and $38 \%$ \\
$9,10,11$ and 12 & 25 & 25 & $1.13,1.58,2.19$ and 2.72 & $33 \%, 34 \%, 36 \%$ and $38 \%$ \\
$13,14,15$ and 16 & 30 & 25 & $1.13,1.58,2.19$ and 2.72 & $33 \%, 34 \%, 36 \%$ and $38 \%$ \\
\hline
\end{tabular}



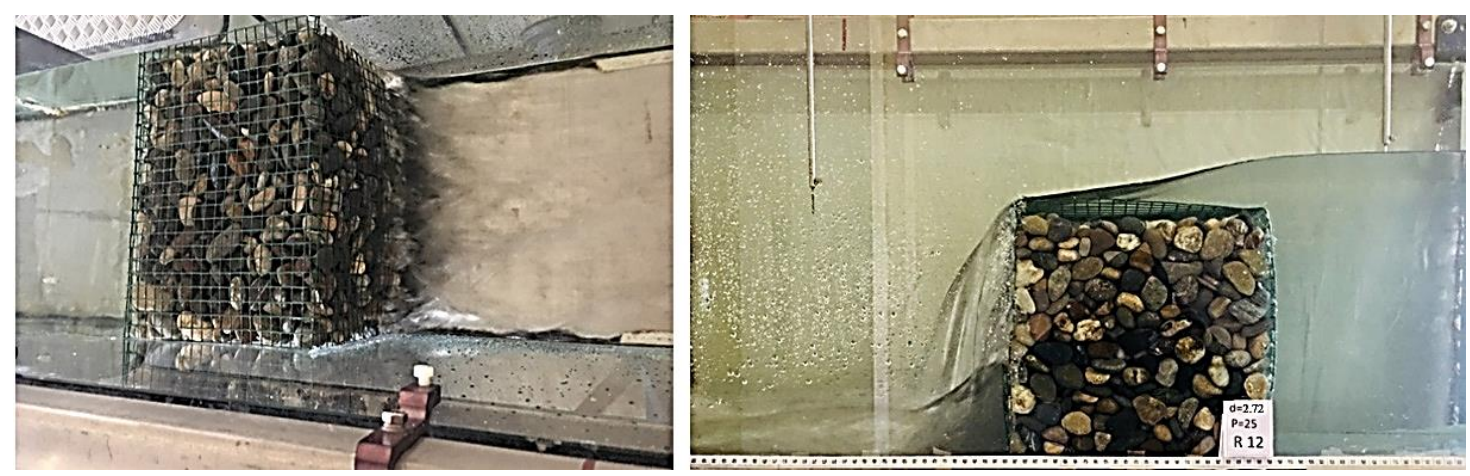

Figure (2) Gabion models in the laboratory open channel.

\section{Results and Discussion}

The incoming flow rates to the gabion structure generate its depth. The flow could pass through gabion only from the upstream face producing what is known as "Through Flow". When the flow rate is increased, it will cover the top surface and flow through the pores of gabion only without free falling to downstream; this state is known as "Transition Flow". These two flow types are illustrated in Figure (1).

In "through flow", the flow depth increases more rapidly when slight increase of discharge happens compared with that which occurs when the flow becomes Transition type, and this is believed to be due to the increase in the area of flow as presented on Figure(3). When the discharge increases more than that in those two states, "Overflow" occurs as a broad-crested weir flow, in which the discharge increases more rapidly due to the increase in flow depth upstream the structure.

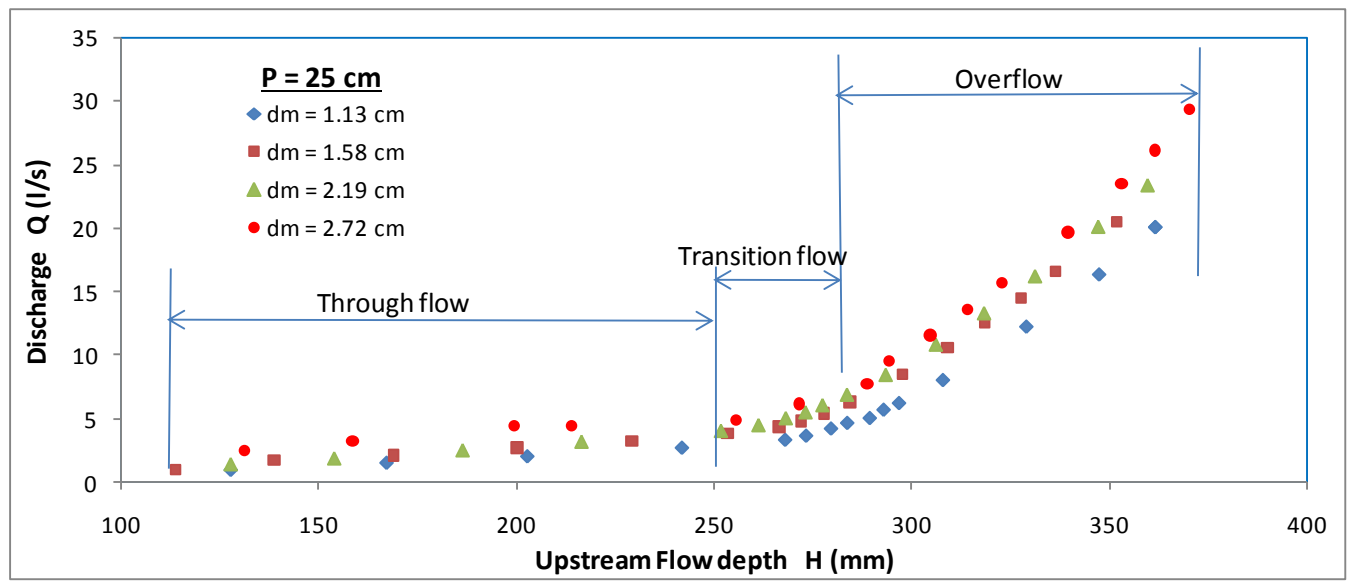

Figure (3) Variation of flow depth with discharge for different aggregate sizes

When the flow passes through the front face of gravel impediment only, the rate of flow in such case depends on the upstream depth and the coarseness of gravel. This variation in presented in Figure (4a), which shows that the larger medium diameter of aggregate allows more rates to pass through for the same head. In this case of flow the height of porous impediment does not affect the rate of flow, but the incoming flow rate will generate an equivalent depth upstream which does not exceed the crest of the gabion and then it is believed that variation be linear as Darcy's proportionality.

Within the limits of the present study, the relative depth of flow $(\Delta \mathrm{H} / \mathrm{H})$ generated upstream reduces between $37 \%$ and $19 \%$ due to the increase in aggregate coarseness from $1.13 \mathrm{~cm}$ to $2.72 \mathrm{~cm}$ and with the increase of Q in "through flow", (i.e. porosity increases from 33\% to 38\%). The average rate of reduction in relative flow depth to the increase in coarseness $(\Delta \mathrm{H} / \Delta \mathrm{dm})$ is $3.4 \%$. The decrease of flow depth is shown in Figure (4b). 
From the data of "through flow" a mathematical relationship is suggested for predicting the upstream flow depth in terms of Q and dm, such that:

$$
\mathrm{H}_{(\mathrm{cm})}=12.907 \mathrm{Q}_{(\mathrm{l} / \mathrm{s})}^{0.618} \mathrm{dm}_{(\mathrm{cm})}^{-0.328} \quad \ldots(8) \quad \mathrm{R}^{2}=0.949
$$

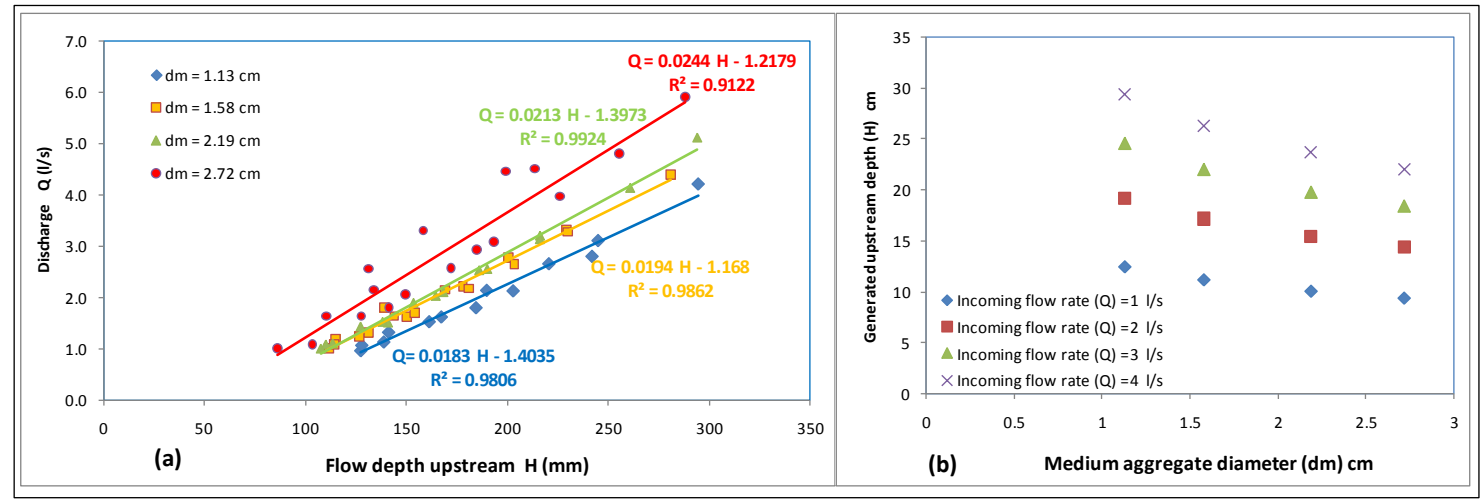

\section{Figure (4) Variation of "through flow" discharge with upstream depth and aggregate size}

When the flow discharge increases to a value that cause a depth of flow exceeding the height of the gabion, at that moment a "transition flow" starts. In this type of flow the water penetrate the front surface and the crest surface. The increase in the surface area of penetration allows passing more discharge for a smaller increase in head compared with that which occurs in "through flow". Figure (5a) shows that a significant increase of the inflow rate causes a mild increase in flow depth for all gabion heights compared with "through flow". Figure (5b) shows the effect of gravel coarseness on the depth of flow for constant gabion height. Crest penetration has a higher effect on $\mathrm{H}$ for low gabion heights compared with those of higher heights. The average decrease in $\mathrm{H}$ is $7.6 \%$ for $\mathrm{P}=15 \mathrm{~cm}$ and $4.4 \%$ for $\mathrm{P}=30 \mathrm{~cm}$ depending on the increase in the flow rate and coarseness. Thus, the overall average reduction in depth is $6 \%$ in this flow regime stage. The experimental data for "transition flow" leads to a relationship for predicting the upstream depth of flow related to Q, $\mathrm{P}$ and $\mathrm{dm}$, presented below:

$$
\mathrm{H}_{(\mathrm{cm})}=2.3 \mathrm{Q}_{(\mathrm{l} / \mathrm{s})}^{0.172} \mathrm{P}_{(\mathrm{cm})}^{0.691} \mathrm{dm}_{(\mathrm{cm})}^{-0.069} \quad \ldots(9) \quad \mathrm{R}^{2}=0.997
$$

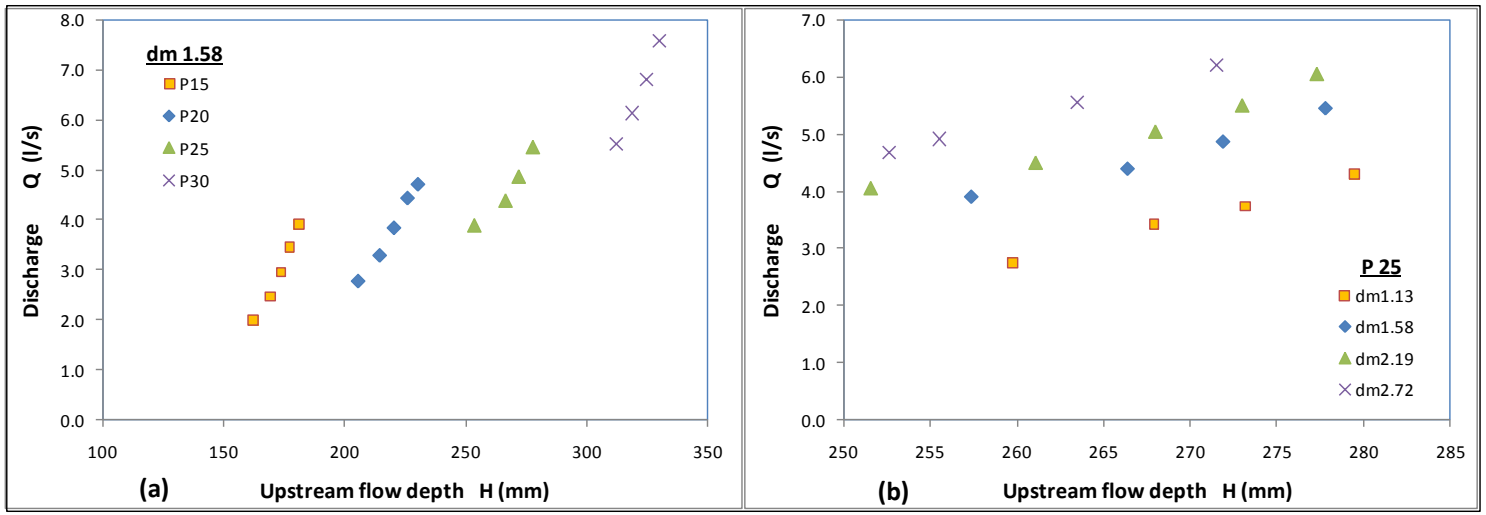

\section{Figure (5) Variation of "Transition Flow" discharge with upstream depth}

The laboratory data and observations show that water starts to fall down from the crest of the gabion when $(\mathrm{H} / \mathrm{P})$ is between 1.14 and 1.23 , producing the "overflow" type, depending on the material coarseness and gabion height. The overall average for noticing this regime flow starts when $\mathrm{H} / \mathrm{P}=1.19$.To present and 
to show the experimental data of this flow, Figure (6) shows the rapid increase in flow discharge related to the increase in flow depth.

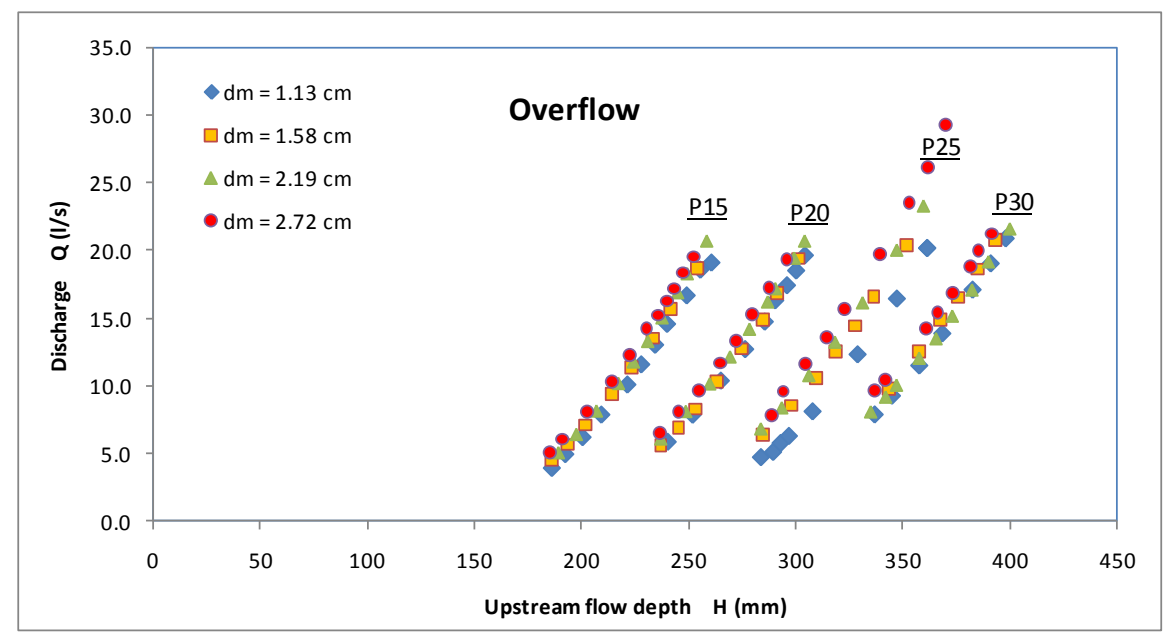

Figure (6) Variation of "overflow" discharge with upstream depth

As the porous media of the gabion allows part the water to flow through, so a solid weir of the same dimensions will generate higher depth in front of it for the same discharge. To make a comparison between Gabions and solid weirs, discharge of broad-weir has been calculated for the experimental values of water depth. The calculations of discharge has been done by employing an equation listed in Subramanya [17].

The calculated value of discharge from the equation and the experimental data for Gabions are presented in Figure (7). It can be noted that gabions accumulate water less than the corresponding solid broad-crested weirs for the same flow rate, especially when the height of the weir increases. The comparisons between discharges of the same water depth show that there is advantage to Gabions. The discharge increase $(\Delta \mathrm{Q} / \mathrm{QSubramanya})$ is from $19 \%$ to $11 \%$ for $\mathrm{P}=15 \mathrm{~cm}$, and from $22 \%$ to $17 \%$ for $\mathrm{P}=30$ $\mathrm{cm}$ depending on material coarseness, with the overall average increase of $15 \%$.

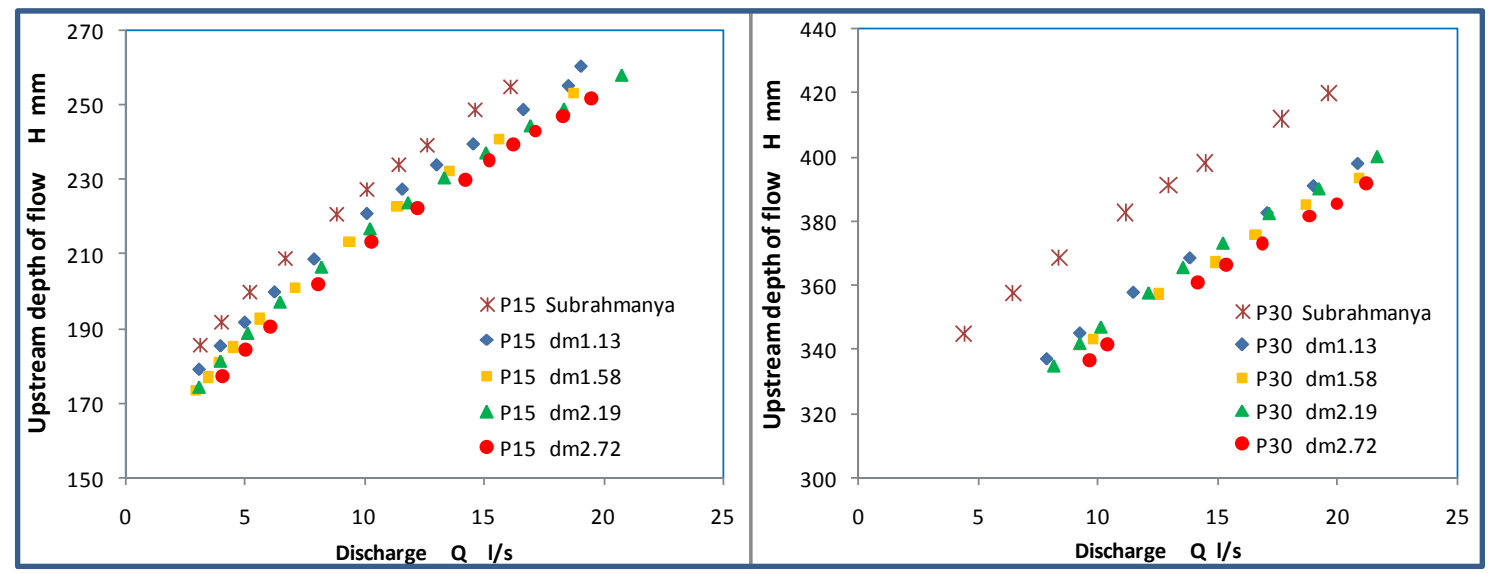

Figure (7) Discharge comparison between gabions and Subramanya weir equation

As gabions generate less water depth in front of them compared to solid ones, it has been found that the percentage of decrease is between $5 \%$ and $7 \%$ for $\mathrm{P}=15 \mathrm{~cm}$, and between $7 \%$ and $9 \%$ for $\mathrm{P}=30 \mathrm{~cm}$ depending on the material coarseness. Figure (8) shows the comparison between the depth values calculated from the weir equation in Subramanya [17] and those measured for the laboratory gabions. The overall percentage of depth decrease can be estimated as $6.5 \%$. 


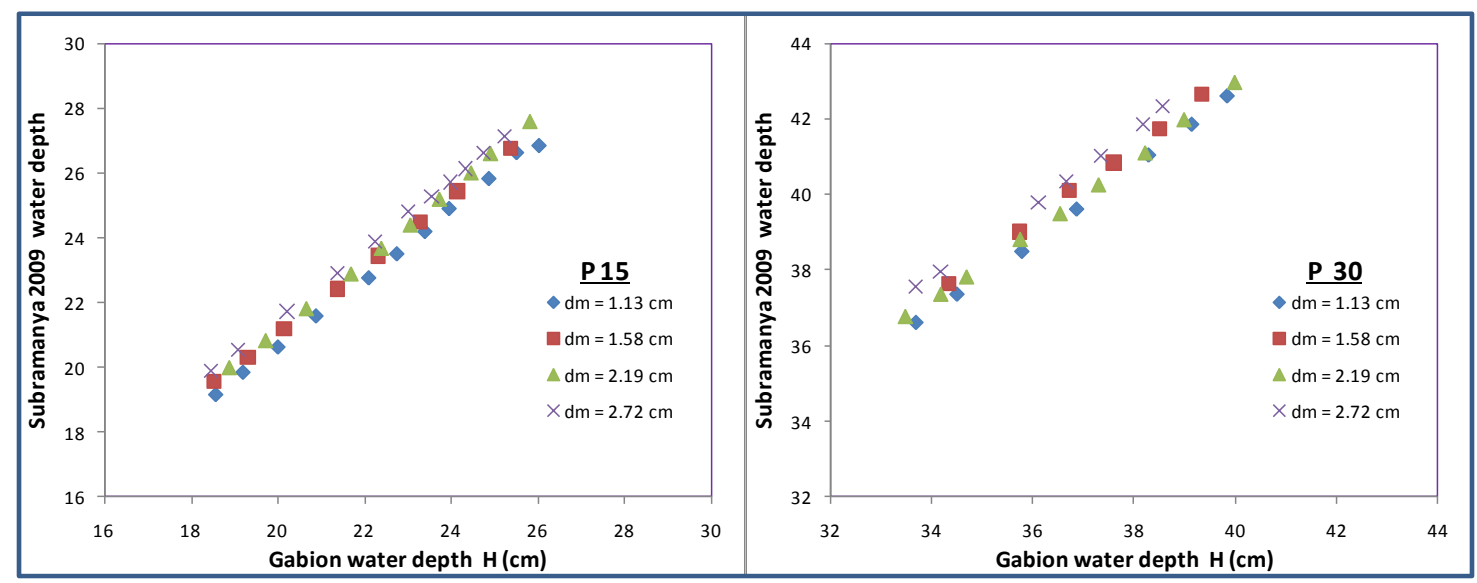

\section{Figure (8) Water depths comparison between gabions and Subramanya broad weir equation}

The nonlinear regression analysis for experimental data of the "overflow" regime yields a relationship for the prediction of the upstream depth of flow as a function of $\mathrm{Q}, \mathrm{P}$ and $\mathrm{dm}$ within the scope of the laboratory work, such that:

$$
\mathrm{H}_{(\mathrm{cm})}=2.441 \mathrm{Q}_{(\mathrm{l} / \mathrm{s})}^{0.191} \mathrm{P}_{(\mathrm{cm})}^{0.656} \mathrm{dm}_{(\mathrm{cm})}^{-0.041} \quad \ldots(10) \quad \mathrm{R}^{2}=0.995
$$

Estimating the flow rate in permeable structures is useful. Gabions in the "overflow" state act as broad-crested weirs. The mathematical model for estimating the discharge coefficient in Equation (7) is carried out by multi-linear regression which has led to the following formula with a standard error of0.0067718:

$$
\mathrm{C}=0.015+0.193 \frac{\mathrm{h}}{\mathrm{P}}+0.096 \frac{\mathrm{d}_{\mathrm{m}}}{\mathrm{P}} \quad \ldots(11) \quad \mathrm{R}^{2}=0.957
$$

\section{Conclusion}

Accumulating water in front of structures for the purpose of storage, measurement or spreading the incoming flood wave can be accomplished by gabion weirs. Data analysis of experimental work with its limitation can lead to forwarding some findings and conclusions.

1- In "through flow", the relative flow depth $(\Delta \mathrm{H} / \mathrm{H})$ decreases from $38 \%$ to $17 \%$ with the increase in coarseness and discharge while the rate of relative reduction in flow depth to the increase in coarseness is $3.4 \%$.

2- In "through flow", the flow depth increases rapidly with a slight increase in the flow rate, compared to "transition flow".

3- For "through flow", a formula is proposed for estimating $\mathrm{H}$ in terms of $\mathrm{Q}$ and $\mathrm{dm}$.

4- In "transition flow", the average decrease in relative flow depth is $7.6 \%$ for $\mathrm{P}=15 \mathrm{~cm}$ and $4.4 \%$ for $\mathrm{P}=30 \mathrm{~cm}$ with the increase of material coarseness and discharge, while the overall average reduction in depth is $6 \%$.

5- For "transition flow", a formula is proposed to estimate $\mathrm{H}$ as a function of $\mathrm{Q}, \mathrm{P}$ and $\mathrm{dm}$.

6- The "overflow" condition starts when the ratio of water depth to gabion height $(\mathrm{H} / \mathrm{P})$ is between 1.14 and 1.23 depending on the material coarseness and gabion height. The overall average for noticing this flow regime is at $\mathrm{H} / \mathrm{P}=1.19$.

7- The overall average of discharge increase $\left(\Delta \mathrm{Q} / \mathrm{Q}_{\text {subramanya }}\right)$ is $15 \%$ and the overall depth decrease is about $6.5 \%$.

8- For "overflow", a formula is proposed to predict $\mathrm{H}$ in terms of $\mathrm{Q}, \mathrm{P}$ and $\mathrm{dm}$.

9- For "overflow", a formula is presented for estimating the discharge coefficient as a function of H/P and $\mathrm{dm} / \mathrm{P}$. 


\section{CONFLICT OF INTERESTS.}

- There are no conflicts of interest.

\section{References}

[1] M. Vicari, 'APPLICATION AND FEEDBACKS OF GABION STRUCTURES IN FLOOD STORAGE PROJECTS FOR THE PROTECTION OF URBAN AREAS AND INFRASTRUCTURES', 34th Dam days 2014 Appl., pp. 2-11, 2014.

[2] H. Chanson, The Hydraulics of Open Channel Flow : An Introduction, 2004th, Seco ed. Linacre House, Jordan Hill, Oxford OX2 8DP 200 Wheeler Road, Burlington, MA 01803: Elsevier ButterworthHeinemann, 2004.

[3] E. Lisle, 'Sediment Transport and Resulting Deposition in Spawning Gravels , North Coastal California', vol. 25, no. 6, pp. 1303-1319, 1989.

[4] M. Mueller, J. Pander, R. Wild, T. Lueders, and J. Geist, 'Limnologica The effects of stream substratum texture on interstitial conditions and bacterial biofilms: Methodological strategies', Limnologica, vol. 43, no. 2, pp. 106-113, 2013.

[5] J. A. Kells, 'Spatially varied flow over rockfill embankments', Can. J. Civ. Eng., vol. 20, no. 5, pp. 820-827, 1993.

[6] V. Te Chow, Open-channel hydraulics. Tokyo: International Student Edition, Kogakusha Company, LTD, 1959.

[7] W. H. Hager and M. Schwalt, 'Broad-Crested Weir', J. Irrig. Drain. Eng., vol. 120, no. 1, pp. 13-26, 1994.

[8] C. A. Gonzalez and H. Chanson, 'Experimental measurements of velocity and pressure distributions on a large broad-crested weir’, Flow Meas. Instrum., vol. 18, pp. 107-113, 2007.

[9] S. Pagliara and I. Lotti, 'Surface and Subsurface Flow through Block Ramps', J. Irrig. Drain. Eng., vol. 135, no. 3, pp. 366-374, 2009.

[10]G. Abozeid, H. I. Mohamed, and S. M. Shehata, 'HYDRAULICS OF CLEAR OVERFALL WEIRS WITH BOTTOM-OPENINGS’, J. Eng. Sci. Assiut Univ., vol. 38, no. 1, pp. 19-28, 2010.

[11]Z. Zachoval, M. Knéblová, L. Roušar, J. Rumann, and J. Šulc, 'Discharge coefficient of a rectangular sharp-edged broad-crested weir', J. Hydrol. Hydromech, vol. 62, no. 2, pp. 145-149, 2014.

[12]M. A.-M. Fadhil and H. M. Saad, 'FLOW THROUGH AND OVER GRAVEL GABION WEIRS', J. Kerbala Univ., vol. 13, no. 2, pp. 193-205, 2015.

[13]S. Grimaldi, P. Vezza, I. Angeluccetti, V. Coviello, and A. M. K. Kô, 'Designing and Building Gabion Check Dams in Burkina Faso', in Engineering Geology for Society and Territory - Volume 3: River Basins, Reservoir Sedimentation and Water Resources, vol. 3, no. i, G. Lollino, M. Arattano, M. Rinaldi, O. Giustolisi, J. C. Marechal, and G. E. Grant, Eds. Springer International Publishing Switzerland, 2015, pp. 529-533.

[14]M. M. Ibrahim, 'Bed Configurations of Downstream Sharp Crested Weir with Orifices', J. Sci. Res. Reports, vol. 9, no. 2, pp. 1-16, 2016.

[15]H. I. Mohamed, 'Flow over Gabion Weirs', J. Irrig. Drain. Eng., vol. 136, no. 8, pp. 573-577, 2010.

[16]F. Salmasi and M. T. Sattari, 'Predicting discharge coefficient of rectangular broad-crested gabion weir using M5 tree model', Iran. J. Sci. Technol. - Trans. Civ. Eng., vol. 41, no. 2, pp. 205-212, 2017.

[17]K. Subramanya, Flow in Open Channels, Third Edit. New Delhi: Tata McGraw-Hill, 2009. 


\section{تأثثير حجم الحصى وارتفاع السد على خصائص تدفق في السداد الحجرية شاكر عبد اللطيف جليل سرحان عبد الستار سرحان أبشكوز صدقي حسين جيهان محمود قاسم قسم هنسة الموارد المائية، كلية الهندسة، جامعة دهوك، العراق}

Jihan.mahmood@uod.ac bshkoj.hussein@uod.ac sarhanabdulsatar@uod.ac shaker.abdulatif@uod.ac

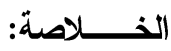

لقد تم دراست العلاقة بين عمق الماء المتجمع امام السداد الحبرية والتصريف القادم من اعالي المجاري المائية في قناة

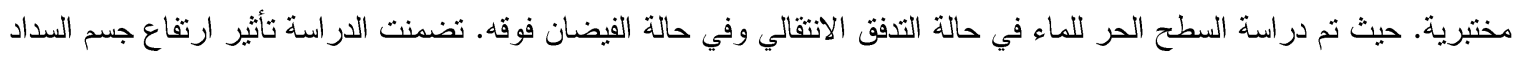

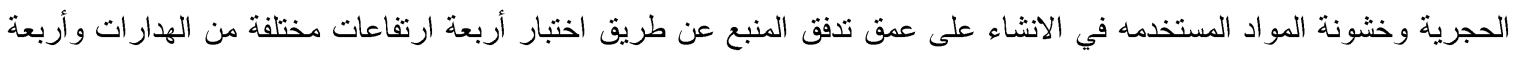

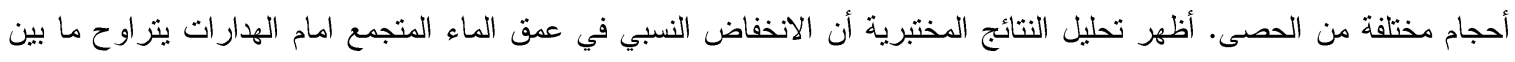

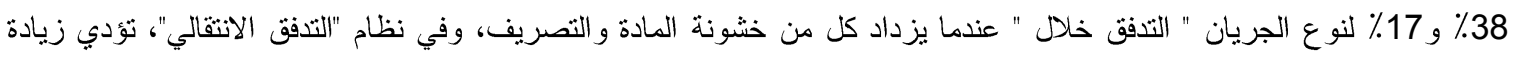

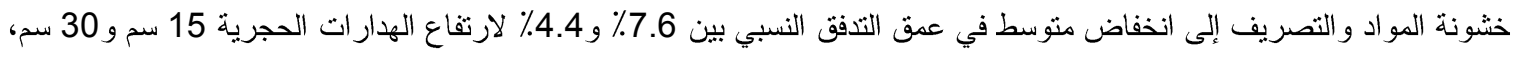

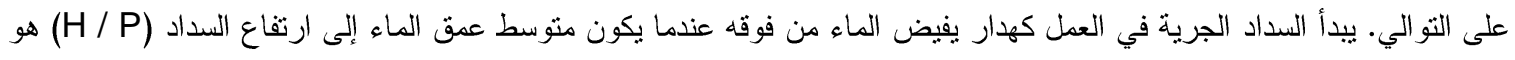

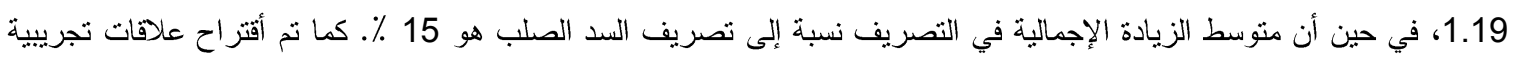

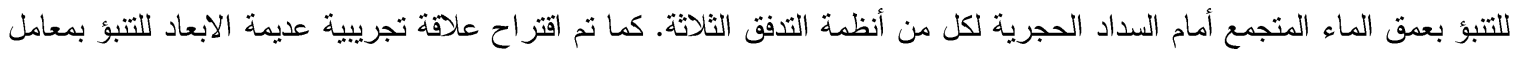
التصريف لهذة السداد وبدقة جيدة. الكلمات الداله: السداد الدجرية، خشونة المو اد، الفائض، التنفق من خلال، التنفق الانتقلي، التنفق الحر. 